УДК 658.14

DOI: https://doi.org/10.37320/2415-3583/14.5

Докієнко Л.М.

кандидат економічних наук, доцент, Міжнародний університет фінансів

ORCID: https://orcid.org/0000-0001-6528-6810

\title{
КОНЦЕПТУАЛЬНІ ПІДХОДИ ДО КОМПЛЕКСНОЇ ДІАГНОСТИКИ ФІНАНСОВОЇ СТІЙКОСТІ ПІДПРИЕМСТВА
}

\begin{abstract}
У статті розглянуто класифікацію типів фінансової стійкості підприємства з їхньою повною характеристикою. Описано методику діагностики та методичний інструментарій оцінки основних типів фінансової стійкості на основі використання коефіиієнтної моделі, моделі модифікованого балансу та системної моделі. Основний акиент зроблено на обтрунтуванні необхідності комплексної діагностики фінансової стійкості підприємства на основі використання системної моделі, щзо дасть змогу управляти фінансовою стійкістю у контексті факторів, щзо визначають ї̈ в поточному чи перспективному періодах. Практичним інструментарісм визначення відповідного стану фінансової стійкості у контексті системної моделі є розроблені матриці можливих станів та ситуацій системної моделі, які дають змогу з повною мірою достовірності оцінити стан фінансової стійкості у певному періоді як наближення до ідеалу чи рівноваги або ж максимальну різницю між бажаним станом та станом небезпеки.
\end{abstract}

Ключові слова: фінансова стійкість, діагностика фінансової стійкості, типи фінансової стійкості, коефіцієнтна модель оиінки фінансової стійкості, модель модифікованого балансу, системна модель оцінки фінансової стійкості.

Постановка проблеми. Управління фінансовою стійкістю підприємства є одним із найбільш значущих функціональних напрямів системи фінансового менеджменту, головною метою якого є забезпечення фінансової безпеки та стабільності функціонування i розвитку підприємства в поточному та перспективному періодах, що дасть змогу в кінцевому підсумку максимізувати його ринкову вартість.

Формування ефективного процесу управління фінансовою стійкістю підприємства диктує необхідність використання і новітніх підходів до його організації. Якість та обгрунтованість управлінських рішень, що приймаються на кожному 3 етапів управління фінансовою стійкістю, значною мірою визначаються не лише достовірністю, повнотою, доступністю та оперативністю отримання інформації, а й ефективністю використовуваних при обробці цієї інформації методів та підходів аналізу.

Відповідно, формування методологічного забезпечення для комплексної діагностики фінансової стійкості підприємства є одним із ключових моментів підвищення ефективності всього процесу управління нею.

Аналіз останніх досліджень і публікацій. Формуванню методичних підходів до оцінки фінансової стійкості підприємства присвячена значна кількість фундаментальних робіт вітчизняних авторів: І.О. Бланка, М.Д.Білик, С.В.Брігхема, В.В.Вітлінського, А.Е.Воронкової, В.М. Гриньової, І.В. Дем'яненко, Л.О. Лігоненко, А.М. Поддєрьогіна, В.П. Савчука, О.О. Терещенка; зарубіжних авторів: М.С. Абрютіної, В.Г. Артеменка, М.В. Белендира, І.Т. Балабанова, Ван Хорна, Л.Т. Гіляровської, В.В. Ковальова, М.Н. Крейніної, О.С. Стоянової, А.Д. Шеремета та інших.

Питання оцінки фінансової стійкості підприємства впродовж останніх років досить широко досліджується у наукових роботах багатьох авторів, але аналіз напрацювань у цій галузі дає змогу зробити висновок, що дослідження зосереджуються лише на певних напря-

мах без їхнього синтезованого подання. Здебільшого сучасні дослідження зводяться до визначення необхідності, сутності та складників фінансової стійкості; завдань, етапів та методів іiі оцінки; розгляду класичних коефіцієнтних методик аналізу, а от питання формування комплексного підходу до діагностики фінансової стійкості підприємства 3 урахуванням сучасних реалій та цифровізації економіки залишаються поза увагою.

Метою статті $є$ обгрунтування сучасних концептуальних підходів до комплексної діагностики фінансової стійкості підприємства на основі узагальненої класифікації її типів.

Виклад основного матеріалу. Фінансова стійкість підприємства являє собою об'єкт фінансового управління господарською діяльністю та характеризує такий стан фінансових ресурсів, їх формування, розподіл і використання, що забезпечує пропорційний, збалансований розвиток підприємства за збереження платоспроможності та кредитоспроможності в умовах припустимого рівня ризику. У вузькому розумінні фінансова стійкість підприємства - це результат ефективного управління структурою капіталу, активів та грошових потоків підприємства.

На думку автора, розглянувши всі наявні у фаховій літературі підходи, варто запропонувати таку класифікацію типів фінансової стійкості підприємства (рис. 1).

Відповідно, поточна фінансова стійкість підприємства - це ситуативна характеристика його діяльності, яка оцінюється суб'єктом аналізу на момент його проведення. Для іï діагностики зазвичай використовують коефіцієнтну модель оцінки фінансової стійкості, яка $\epsilon$ найбільш популярною та поширеною у використанні й описується більшістю сучасних фахівців [3; $4 ; 5 ; 7 ; 8 ; 11]$. Узагальнивши наявний досвід, пропонуємо у складі коефіцієнтної моделі виділяти фінансові коефіцієнти, що характеризують ефективність управління структурою капіталу, активів та грошових потоків підприємства (рис. 2). 


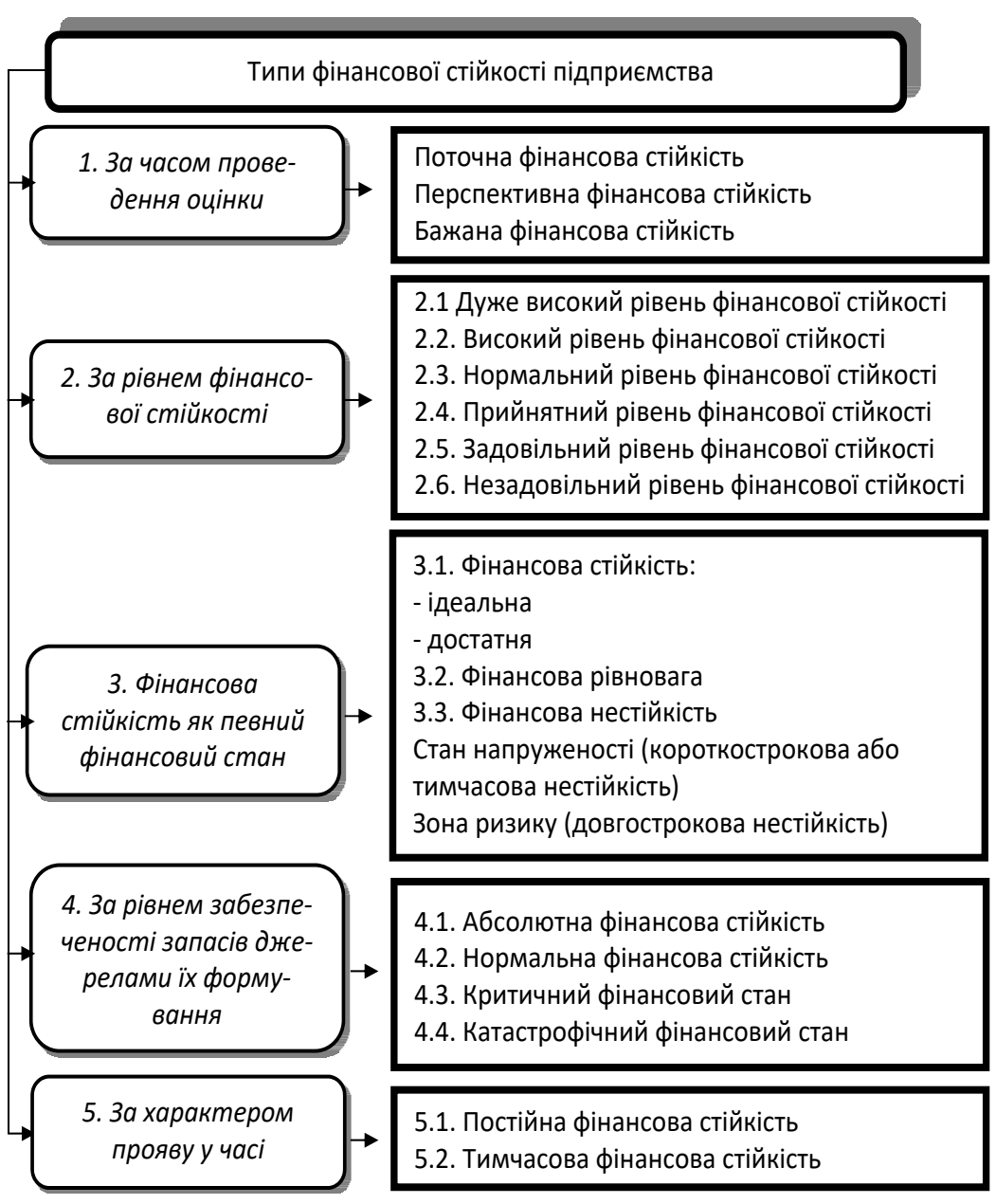

Рисунок 1 - Класифікація типів фінансової стійкості підприємства

Джерело: складено автором на основі [1; 3; 9; 11$]$

3 метою підвищення ступеню інформативності коефіцієнтної моделі та визначення рівня фінансової стійкості підприємства, а також забезпечення ії комплексності пропонується згрупувати наведені вище фінансові показники у матриці:
I. Показники, для яких визначається нормативне значення, або показники першого класу - коефіцієнти структури капіталу, коефіцієнти, що визначають стан оборотних активів та допоміжні коефіцієнти фінансової стійкості (табл. 1).

II. Показники, для яких нормативні значення, як правило, не встановлюються, або показники другого класу абсолютні показники фінансової стійкості, коефіцієнти забезпеченості та показники структури грошових потоків. Для їх оцінки використовуються такі стани: «покращення» - 1; «стабільність» -2 ; «погіршення» -3 .

Далі доцільно поєднати вищевказані показники у загальну матрицю, структура якої наведена у таблиці 2.

Отже, з'являється можливість врахувати внутрішні та зовнішні фактори, які визначають фінансову стійкість підприємства.

Таким чином, дуже високий та високий рівень фінансової стійкості підприємства - такий стан фінансових ресурсів, їх формування, розподілу та використання, що забезпечує стабільний, прискорений розвиток підприємства за збереження платоспроможності та кредитоспроможності, більшість показників оцінки фінансової стійкості відповідає рекомендованим (бажаним) значенням. Тобто більшість коефіцієнтів фінансової стійкості перевищують порогові (рекомендовані) критеріальні значення та покращуються.

Нормальний та прийнятний рівень фінансової стійкості підприємства, який не завжди є бажаним, але задовольняє керівництво підприємства у певному періоді часу. Може проявлятися у ситуації погіршення окремих часткових показників фінансової стійкості, але не торкатися суттєво іiі загалом, оскільки

Таблиця 1 - Матриця фінансових показників першого класу для оцінки рівня фінансової стійкості підприсмства

\begin{tabular}{|c|c|c|c|}
\hline Тенденції & 1. Покращення значення & 2. Стабільність значення & 3. Погіршення значення \\
\hline $\begin{array}{l}\text { 1. Нормативне } \\
\text { значення }\end{array}$ & $\begin{array}{l}\text { «Дуже добре» } \\
\text { «Да } \\
\text { Значення показника повністю } \\
\text { відповідає нормативному зна- } \\
\text { ченню, або ж наближається до } \\
\text { нього }\end{array}$ & \begin{tabular}{l}
1.2. \\
\multicolumn{1}{|c|}{ «Нормально-дуже добре» } \\
Значення показників стійкі та на \\
рівні нормативних - оцінка «дуже \\
добре»; якщо значення показників \\
біля меж коридору стійких значень - \\
оцінка «нормально»
\end{tabular} & $\begin{array}{l}\text { «Нормально» } \\
\text { Значення показників на рівні нор- } \\
\text { Зативів, але спостерігається тенден- } \\
\text { ція руху значень від середини } \\
\text { коридору до границь нормативів - } \\
\text { оцінка «нормально» }\end{array}$ \\
\hline $\begin{array}{l}\text { 2. Не } \\
\text { відповідність } \\
\text { нормативам }\end{array}$ & \begin{tabular}{|c|}
\multicolumn{1}{|c|}{2.1.} \\
«Задовільно-нормально» \\
Значення показників за межами \\
нормативів, але відбувається \\
тенденція до іх покращення - \\
оцінка «нормально» чи «задо- \\
вільно» в залежності від роз- \\
міру відхилень та темпів руху \\
до нормативних значень
\end{tabular} & \begin{tabular}{|c|}
\multicolumn{1}{|c|}{2.2.} \\
«Незадовільно-задовільно» \\
Значення показників постійно від- \\
хиляються від нормативних-оцінка \\
«задовільно» чи «незадовільно» в \\
залежності від рівня відхилень \\
\end{tabular} & \begin{tabular}{c}
\multicolumn{2}{c}{2.3.} \\
«Незадовільно» \\
Значення показників поки що постійно \\
відхиляються від нормативних чи \\
спостерігається тенденція погіршення \\
показників - оцінка «незадовільно»
\end{tabular} \\
\hline
\end{tabular}

Джерело: складено автором 
ці показники все ще знаходяться у допустимих межах.

Задовільний та незадовільний рівень фінансової стійкості підприємства характеризується погіршенням всіх показників фінансової стійкості, відсутністю можливості підприємства подолати своїми силами стан потенційної або повної неплатоспроможності.

Перспективна фінансова стійкість підприємства - це характеристика його діяльності у майбутньому, тобто ймовірність того, що фінансові можливості підприємства протягом певного часу будуть відповідати відповідним встановленим критеріям. Іншими словами, це здатність підприємства у довгостроковому плані стабільно генерувати доходи, достатні для виконання зобов'язань перед інвесторами, та задовольняти інтереси власників. Її прогнозування здійснюють iз використанням класичних методів фінансового планування (для розроблення балансового плану та плану доходів і витрат) і планових розрахунків класичних показників фінансової стійкості, що використовувалися для оцінки поточної фінансової стійкості.

Бажана фінансова стійкість підприємства визначається підприємством самостійно, виходячи 3 його можливостей та потреб в тому чи іншому періоді і 3 використанням вибраного методу діагностики фінансової стійкості.

Фінансову стійкість як певний фінансовий стан підприємства пропонується діагностувати на основі використання моделі модифікованого балансу (табл. 3).

Відповідно, фінансова стійкість: може бути ідеальною за умови, що сума власного капіталу підприємства перевищує суму немобільних активів, та достатньою, якщо сума власного капіталу менша за суму немобільних активів, але більша за суму нефінансових активів.

Фінансова рівновага витримується, коли сума власного капіталу дорівнює сумі нефінансових активів, а позикового - сумі фінансових активів.

Зона фінансової нестійкості у разі, коли сума власного капіталу менша за суму нефінансових активів. Вона може проявлятися у стані напруженості та, від-
Типи фінансової стійкості підприємства

\section{Поточна фінансова стійкість}

Перспективна фінансова стійкість

Бажана фінансова стійкість

2.1 Дуже високий рівень фінансової стійкості

2.2. Високий рівень фінансової стійкості

2.3. Нормальний рівень фінансової стійкості

2.4. Прийнятний рівень фінансової стійкості

2.5. Задовільний рівень фінансової стійкості

2.6. Незадовільний рівень Фінансової стійкості

3.1. Фінансова стійкість:

- ідеальна

- достатня

3.2. Фінансова рівновага

3.3. Фінансова нестійкість

Стан напруженості (короткострокова або

тимчасова нестійкість)

Зона ризику (довгострокова нестійкість)

.1. Абсолютна фінансова стійкість

4.2. Нормальна фінансова стійкість

4.3. Критичний фінансовий стан

4.4. Катастрофічний фінансовий стан

5.1. Постійна фінансова стійкість

5.2. Тимчасова фінансова стійкість

Рисунок 2 - Групи показників для оцінки фінансової стійкості підприсмства

Таблиця 2 - Матриця фінансових показників для визначення рівня фінансової стійкості підприсмства на базі використання коефіціснтної моделі

Таблиця 2 - Матриця фінансових показників для визначення рівня фінансової стійкості підприсмства
на базі використання коефіціснтної моделі
\begin{tabular}{|l|c|c|c|}
\hline \multicolumn{1}{|c|}{ Стан показників першого класу } & Стан показників другого класу & Оцінка & Рівень фінансової стійкості \\
\hline $\begin{array}{l}\text { 1.1. «Дуже добре» } \\
\text { 1.2. «Нормально-дуже добре» }\end{array}$ & 1. «Покращення» & Відмінно & Дуже високий \\
\hline $\begin{array}{l}\text { 1.3. «Нормально» } \\
\text { 2.1. «Задовільно-нормально» }\end{array}$ & 2. «Стабільність» & Доже добре & Високий \\
\hline $\begin{array}{l}\text { 2.2. «Незадовільно-задовільно» } \\
\text { 2.3. «Незадовільно» }\end{array}$ & 3. «Погіршення» & Нормально & Нормальний \\
\cline { 2 - 4 }
\end{tabular}

Джерело: складено автором повідно, може бути короткостроковою (коли підприємство не може у встановлений строк погасити прострочену заборгованість, але має інтенсивний притік прибутку, що дозволить погасити іiі разом із нещодавно залученими коштами у нормативно встановлений період) та тимчасовою (коли підприємство не має достатньо коштів для своєчасного погашення зовнішньої заборгованості, але за рахунок мобілізації частини ліквідних або неліквідних активів зможе покрити свої зобов'язання), або наближатися до зони ризику, тобто бути довгостроковою (коли підприємство може погасити борги лише за рахунок мобілізації всіх наявних коштів).

За рівнем забезпеченості запасів джерелами їх формування фінансова стійкість може бути абсолютною,

- 
Таблиця 3 - Види фінансової стійкості підприємства за узагальненою та диференційованою шкалою (модель модифікованого балансу)

\begin{tabular}{|c|c|c|}
\hline \multicolumn{2}{|c|}{ Шкала фінансової стійкості } & \multirow{2}{*}{ Умовні позначення* } \\
\hline Узагальнена & Диференційована & \\
\hline \multirow{2}{*}{$\begin{array}{l}\text { Фінансова } \\
\text { стійкість }\end{array}$} & $\begin{array}{c}\text { Ідеальна стійкість } \\
\mathrm{HM}_{\mathrm{A}}<\mathrm{BK}<\mathrm{EA} \\
\mathrm{HM}_{\Phi \mathrm{A}}<\mathrm{I}_{\Phi \mathrm{\Phi C}}<\text { ФА }\end{array}$ & \multirow{5}{*}{ 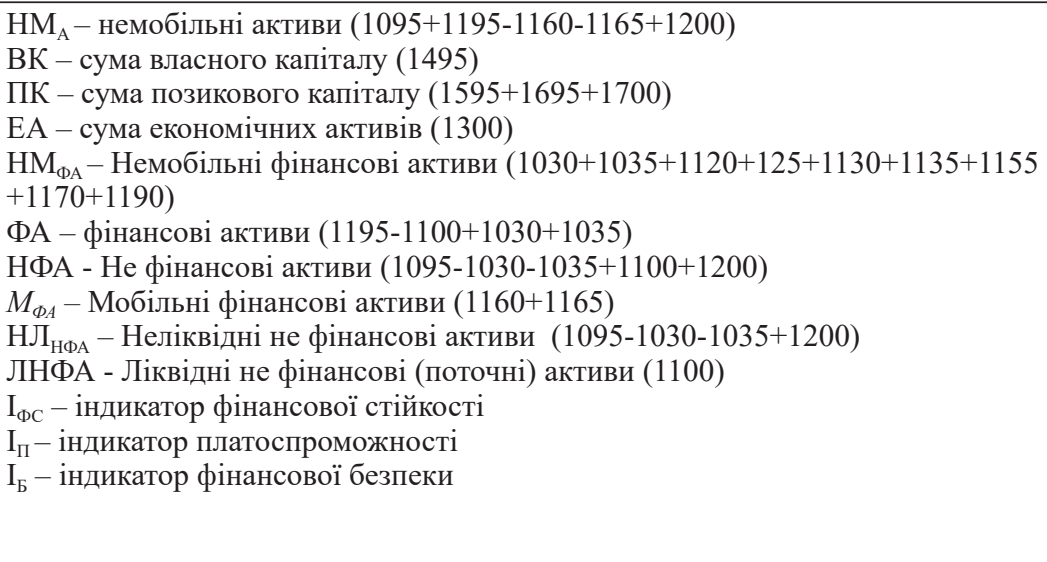 } \\
\hline & $\begin{array}{c}\text { Достатня стійкість } \\
0<\mathrm{H} \Phi \mathrm{A}<\mathrm{BK}<\mathrm{HM}_{\mathrm{A}} \\
0<\mathrm{I}_{\Phi \mathrm{C}}<\mathrm{HM}_{\Phi \mathrm{A}}\end{array}$ & \\
\hline $\begin{array}{l}\text { Фінансова } \\
\text { рівновага }\end{array}$ & $\begin{array}{c}\mathrm{I}_{\Phi C}=0 ; I_{\Phi C}=B K-H \Phi A \\
\mathrm{I}_{\Pi}<0 ; I_{\Pi}=M_{\Phi A}-\Pi K \\
\mathrm{I}_{Б}>0 ; I_{Б}=B K-\mathrm{H}_{\mathrm{HФA}}\end{array}$ & \\
\hline \multirow{2}{*}{$\begin{array}{l}\text { Фінансова } \\
\text { нестійкість }\end{array}$} & $\begin{array}{c}\text { Hапруженість } \\
0<\mathrm{H}_{\mathrm{H} \Phi \mathrm{A}}<\mathrm{BK}<\mathrm{H} \text { АА } \\
-\mathrm{JH}_{\Phi \mathrm{A}}<\mathrm{I}_{\Phi \mathrm{C}}<0\end{array}$ & \\
\hline & $\begin{array}{c}\text { Зона ризику } \\
0<\mathrm{BK}<\mathrm{H}_{\mathrm{HФA}} \\
-\mathrm{H} Ф \mathrm{~A}<\mathrm{I}_{\Phi \mathrm{C}}<-Л_{\Phi \mathrm{A}}\end{array}$ & \\
\hline
\end{tabular}

* в дужках вказані коди рядків фінансової звітності - Форма №1 «Баланс» (звіт про фінансовий стан)

Джерело: складено автором на основі [1]

нормальною, критичною та катастрофічною [2; $3 ; 8$; $10 ; 11]$.

Абсолютна фінансова стійкість підприємства досягається за умови, коли підприємство має суму власних оборотних активів, яка більша за суму його запасів; характерна для підприємств із рівноважним фінансовим циклом, тобто вільні кошти генеруються після сплати заборгованості; при цьому підприємство має максимальну безпеку.

Нормальна або достатня фінансова стійкість підприємства, коли сума його запасів більша за суму власних оборотних активів, але менша за суму нормальних джерел фінансування запасів; коли фінансовий цикл підприємства є дефіцитним, однак залучені фінансові ресурси і відсотки за ними можуть бути сплачені за рахунок адекватного заміщення операційного циклу; безпека підприємства оптимальна, положення надійне, платоспроможність гарантована.

Критичний фінансовий стан підприємства, або зона напруженості - коли сума запасів перевищує суму нормальних джерел фінансування; фінансовий цикл дефіцитний; безпека ще деякою мірою зберігається, але вона відносна, платоспроможність має лише потенційний характер;

Катастрофічний фінансовий стан підприємства, або зона ризику, існує, якщо поряд із попередньою умовою підприємство має прострочені кредити та позики, що свідчить про порушення платіжної дисципліни в розрахунках з кредиторами; безпека відсутня, платоспроможність втрачена, з'являється ризик, який змінюється від мінімального до максимального.

Постійна фінансова стійкість підприємства характерна для певного періоду його діяльності (звітного періоду, стадії життєвого циклу) та пов'язана з дією постійних факторів, які можна передбачити. А тимчасова фінансова стійкість підприємства носить перманентний характер, що виникає лише на окремих етапах здійснення певної фінансово-господарської операції (наприклад, підприємство залучило на короткостроковий період кредитні ресурси, як результат впродовж часу його використання воно може бути неплатоспроможним, але прибутковим; після погашення кредиту фінансова стійкість підприємства автоматично відновлюється).

Таким чином, модельний інструментарій оцінки більшості 3 виділених типів фінансової стійкості $€$ зрозумілим, виходячи 3 трактування їх сутності, а комплексно здійснити оцінку фінансової стійкості підприємства вбачається за можливе 3 використанням системної моделі, тобто у контексті факторів, що визначають позитивні чи негативні зміни як у галузі діяльності підприємства загалом, так і у ньому безпосередньо. Реалізувати зазначений підхід пропонується у межах системного моделювання на основі концепції меж зростання [6].

Кожне підприємство функціонує у деякому просторі, що $є$ простором його життєдіяльності. Він відображає позитивний чи негативний простір, який сприяє успішному функціонуванню галузі загалом та окремого підприємства зокрема або посилює кризові явища. У кожен момент часу фінансова стійкість підприємства характеризується певним набором показників. Вектор показників фінансової стійкості $\left(Ф C_{\Pi}\right)$ у кожен момент часу $\left(\mathrm{ч}_{\mathrm{i}}\right)$ визначає стан фінансової стійкості підприємства $Ф \mathrm{C}_{\Pi}\left(\mathrm{ч}_{\mathrm{i}}\right)$. Вся сукупність часткових та інтегральних показників фінансової стійкості може розподілятися на групи - r.

Розвиток підприємства можливий у позитивному (прогресивному) чи негативному (регресивному) напрямах або ж можлива відсутність розвитку - стагнація. Негативним полюсом чи рівнем регресу підприємства $\epsilon$ межа небезпеки чи катастрофи - ФС $\mathrm{C}_{\text {п }}\left(\mathrm{ч}_{\mathrm{i}}\right)$, позитивним полюсом чи рівнем прогресу є межа досконалості або

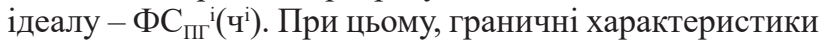
“позитивного чи негативного" для кожного підприємства можуть варіювати у часі та мати істотно різні значення 3 огляду на відповідну специфіку їх функціональної діяльності, розмір, організаційно-правову форму та інше. Вся сукупність показників фінансової стійкості підприємства 3 плином часу або змінюється, або залишається незмінною. Зміна цих показників $\epsilon$ 
розвитком підприємства, який може мати позитивну спрямованість - у напрямі межі досконалості, або негативну - у напрямі межі небезпеки (табл. 4).

Безперечно, головна мета для підприємства - знайти бажане значення ФСПГб, яке б відповідало виваженому управлінському рішенню. Але на практиці ситуація, коли всі компоненти відомі, трапляється досить рідко, більш характерним є часткове знання або часткова невизначеність, коли невідомим $є$ або ідеал, або стан катастрофи, або очікуваний чи досягнутий стан i, відповідно підприємство може знаходитися в одній із 32 можливих ситуацій (табл. 5). Отже, у контексті запропонованої системної моделі головну мету управління фінансовою стійкістю підприємства можна визначити як наближення до ідеалу або ж максимальну різницю між бажаним станом та станом небезпеки.

Перевагою використання запропонованої систем- ної моделі є те, що ії використання носить практично безперервний характер у процесі управління фінансовою стійкістю, оскільки після виявлення недоліків (наприклад, ситуації погіршення рівня фінансової стійкості на основі розрахунку часткових чи інтегральних показників) автоматично діюча система управління нею переводить iї у новий стан та забезпечує іiї підтримання на цьому рівні.

Діагностика фінансової стійкості на базі системної моделі повинна здійснюватися безперервно, щоб вона постійно відповідала бажаному стану фінансової стійкості та цілям управління. Поряд із визначенням внутрішньої організації системної моделі надзвичайно важливе значення має і точність визначення меж іiі функціонування, i, оскільки виконання цього завдання є одним із найскладніших, це є найслабшою рисою цієї моделі.

Таблиця 4 - Матриця станів фінансової стійкості підприємства у контексті системної моделі

\begin{tabular}{|c|c|c|c|}
\hline \multirow{2}{*}{ Стан фінансової стійкості } & \multicolumn{3}{|c|}{ Стаціонарні інтервали часу } \\
\hline & Минулий & Теперішній & Майбутній \\
\hline$\Phi \mathrm{C}_{\Pi \Gamma}^{\mathrm{i}}$ & $\Phi C_{\Pi Г}{ }^{\text {i }}\left(\mathrm{ч}_{\mathrm{i}}{ }^{\text {мин }}\right)$ & $\Phi C_{\Pi \Gamma}^{i}\left({u_{i}}^{\mathrm{T}}\right)$ & $\Phi \mathrm{C}_{\Pi \Gamma}{ }^{\mathrm{i}}\left(\mathrm{บ}_{\mathrm{i}}\right.$ майб $)$ \\
\hline$\Phi \mathrm{C}_{\Pi \Gamma^{2}}{ }^{2}$ & $\Phi C_{П Г}{ }^{\text {д }}\left(\mathrm{ч}_{\mathrm{i}}{ }^{\text {мин }}\right)$ & $\Phi C_{\Pi \Gamma}{ }^{2}\left(\mathrm{u}_{\mathrm{i}}{ }^{\mathrm{T}}\right)$ & $\Phi C_{\Pi \Gamma}{ }^{\text {म}}\left(ч_{\mathrm{i}}{ }^{\text {майб }}\right)$ \\
\hline$\Phi C_{\Pi \Gamma}^{p}$ & $\Phi \mathrm{C}_{\Pi \Gamma}{ }^{\mathrm{p}}\left(\mathrm{u}_{\mathrm{i}}{ }^{\text {мин }}\right)$ & $\Phi C_{\Pi \Gamma}{ }^{p}\left(u_{i}{ }^{\mathrm{T}}\right)$ & $\Phi \mathrm{C}_{\Pi \Gamma}{ }^{\mathrm{p}}\left(\mathrm{u}_{\mathrm{i}}{ }^{\text {майб }}\right)$ \\
\hline$\Phi \mathrm{C}_{\Pi \Gamma}^{\text {н }}$ & $\Phi C_{П Г}{ }^{\text {н }}\left(\mathrm{ч}_{\mathrm{i}}{ }^{\text {мин }}\right)$ & $\Phi C_{\Pi \Gamma}{ }^{\mathrm{H}}\left(\mathrm{u}_{\mathrm{i}}{ }^{\mathrm{T}}\right)$ & $\Phi \mathrm{C}_{П Г}{ }^{\text {н }}\left(\mathrm{\Psi}_{\mathrm{i}}{ }^{\text {майб }}\right)$ \\
\hline$\Phi \mathrm{C}_{\Pi \Gamma}$ по & $\Phi \mathrm{C}_{\Pi Г}{ }^{\text {по }}\left(\mathrm{ч}_{\mathrm{i}}{ }^{\text {мин }}\right)$ & $\Phi \mathrm{C}_{\Pi \Gamma}{ }^{\mathrm{no}}\left(\mathrm{u}_{\mathrm{i}}{ }^{\mathrm{T}}\right)$ & $\Phi \mathrm{C}_{\Pi \Gamma}{ }^{\text {по }}\left(\mathrm{(}_{\mathrm{i}}{ }^{\text {майб }}\right)$ \\
\hline$\Phi \mathrm{C}_{\Pi \Gamma}$ пе & $\Phi \mathrm{C}_{\Pi \Gamma}{ }^{\text {пе }}\left(\mathrm{ч}_{\mathrm{i}}{ }^{\text {мин }}\right)$ & $\Phi \mathrm{C}_{\Pi \Gamma}{ }^{\mathrm{ne}}\left(\mathrm{u}_{\mathrm{i}}{ }^{\mathrm{T}}\right)$ & $\Phi \mathrm{C}_{\Pi \Gamma}{ }^{\text {пе }}\left(\mathrm{Ч}_{\mathrm{i}}{ }^{\text {майб}}\right)$ \\
\hline$\Phi \mathrm{C}_{\Pi \Gamma}{ }^{\sigma}$ & $\Phi \mathrm{C}_{\Pi \Gamma}{ }^{\sigma}\left(\mathrm{\Psi}_{\mathrm{i}}{ }^{\text {мин }}\right)$ & $\left.\Phi \mathrm{C}_{\Pi \Gamma}{ }^{\sigma} \mathbf{u}_{i}{ }^{\mathrm{T}}\right)$ & $\Phi C_{\Pi \Gamma}{ }^{\sigma}\left(\mathrm{\Psi}_{\mathrm{i}}{ }^{\text {майб}}\right)$ \\
\hline
\end{tabular}

Джерело: складено автором на основі [6]

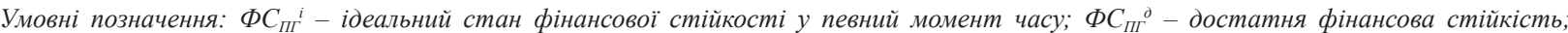

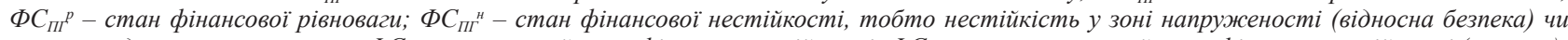

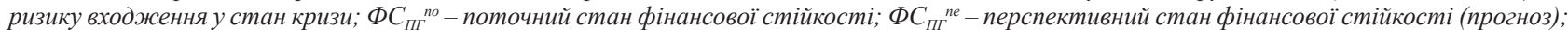
$\Phi C_{\Pi Г}{ }^{6}-$ бажаний стан фінансової стійкості, який відповідає певному управлінському ріменню.

Таблиця 5 - Матриця ситуацій системної моделі оцінки фінансової стійкості підприємства

\begin{tabular}{|c|c|c|c|c|c|c|}
\hline \multirow{3}{*}{ Множина інформаційних ситуацій } & \multicolumn{6}{|c|}{ Рівні знання } \\
\hline & \multicolumn{4}{|c|}{ Граничні } & \multicolumn{2}{|c|}{ Поточні } \\
\hline & $\Phi \mathbf{C}_{n \Gamma}^{i}$ & $\Phi \mathbf{C}_{\Pi \Gamma}{ }^{\mu}$ & $\Phi \mathbf{C}_{\Pi \Gamma}^{p}$ & $\Phi \mathbf{C}_{\Pi \Gamma}{ }^{H}$ & $\Phi \mathbf{C}_{\Pi \Pi \Gamma}{ }^{\text {"10 }}$ & $\Phi C_{\Pi \Gamma}{ }_{n+}^{\text {ne }}$ \\
\hline 1 & 2 & 3 & 4 & 5 & 6 & 7 \\
\hline 1. Ситуація повного знання & + & + & + & + & + & + \\
\hline 2. Ситуація невизначеності тенденцій & + & + & + & + & + & - \\
\hline 3. Ситуація невизначеності дійсності & + & + & + & + & - & + \\
\hline 4. Ситуація невизначеності дійсності і тенденцій & + & + & + & + & - & - \\
\hline 5. Ситуація невизначеності кризи & + & + & + & - & + & + \\
\hline 6. Ситуація невизначеності кризи і дійсності & + & + & + & - & - & + \\
\hline 7. Ситуація невизначеності кризи і тенденцій & + & + & + & - & + & - \\
\hline 8. Ситуація невизначеності кризи, тенденцій і дійсності & + & + & + & - & - & - \\
\hline 9. Ситуація невизначеності рівноваги & + & + & - & + & + & + \\
\hline 10. Ситуація невизначеності рівноваги і дійсності & + & + & - & + & - & + \\
\hline 11. Ситуація невизначеності рівноваги і тенденцій & + & + & - & + & + & - \\
\hline $\begin{array}{l}\text { 12. Ситуація невизначеності рівноваги, тенденцій і } \\
\text { дійсності }\end{array}$ & + & + & - & + & - & - \\
\hline $\begin{array}{l}\text { 13. Ситуація невизначеності рівноваги, кризи, тенденцій } \\
\text { і дійсності }\end{array}$ & + & + & - & - & - & - \\
\hline
\end{tabular}




\begin{tabular}{|c|c|c|c|c|c|c|}
\hline \multicolumn{7}{|c|}{ Продовження Таблиці } \\
\hline 1 & 2 & 3 & 4 & 5 & 6 & 7 \\
\hline 14. Ситуація невизначеності достатності & + & - & + & + & + & + \\
\hline 15. Ситуація невизначеності достатності і дійсності & + & - & + & + & - & + \\
\hline 16. Ситуація невизначеності достатності і тенденцій & + & - & + & + & + & - \\
\hline $\begin{array}{l}\text { 17. Ситуація невизначеності достатності, тенденцій } \\
\text { і дійсності }\end{array}$ & + & - & + & + & - & - \\
\hline $\begin{array}{l}\text { 18. Ситуація невизначеності достатності, кризи, } \\
\text { тенденцій і дійсності }\end{array}$ & + & - & + & - & - & - \\
\hline 19. Ситуація невизначеності ідеалу & - & + & + & + & + & + \\
\hline 20. Ситуація невизначеності ідеалу і дійсності & - & + & + & + & - & + \\
\hline 21. Ситуація невизначеності ідеалу і тенденцій & - & + & + & + & + & - \\
\hline 22. Ситуація невизначеності ідеалу, тенденцій і дійсності & - & + & + & + & - & - \\
\hline 23. Ситуація невизначеності ідеалу, катастрофи і дійсності & - & + & + & - & - & + \\
\hline $\begin{array}{l}\text { 24. Ситуація невизначеності ідеалу, катастрофи і } \\
\text { тенденцій }\end{array}$ & - & + & + & - & + & - \\
\hline $\begin{array}{l}\text { 25. Ситуація невизначеності ідеалу, катастрофи, дійсності } \\
\text { та тенденцій }\end{array}$ & - & + & + & - & - & - \\
\hline 26. Ситуація невизначеності ідеалу та рівноваги & - & + & - & + & + & + \\
\hline 27. Ситуація невизначеності ідеалу та достатності & - & - & + & + & + & + \\
\hline 28. Ситуація невизначеності ідеалу, достатності та рівноваги & - & - & - & + & + & + \\
\hline 29. Ситуація невизначеності меж розвитку & - & - & - & - & + & + \\
\hline 30. Ситуація невизначеності меж розвитку та дійсності & - & - & - & - & - & + \\
\hline 31. Ситуація невизначеності меж розвитку та тенденцій & - & - & - & - & + & - \\
\hline 32. Ситуація повної невизначеності & - & - & - & - & - & - \\
\hline
\end{tabular}

Джерело: складено автором на основі [6]

Висновки. Комплексна діагностика фінансової стійкості підприємства на основі розглянутих концептуальних підходів та моделей дасть змогу суттєво підвищити ефективність процесу управління фінан-

совою стійкістю підприємства як у поточному, так і в перспективному періодах, забезпечити високий рівень інвестиційної привабливості та фінансової безпеки підприємства.

\section{Список використаних джерел:}

1. Абрютина М.С. Оценка финансовой устойчивости и платежеспособности российских компаний. Финансовый менеджмент. 2006. № 6. С. 28-34.

2. Белялов Т.Е., Олійник А.В. Фінансова стійкість підприємства та шляхи ії̈ зміцнення. Міжнародний науковий журнал «Інтернаука». 2016. № 12 (22). 2 т. С. 22-26.

3. Бланк И.А. Управление финансовой стабилизацией предприятия. Энщиклопедия финансового менеджера. Выпуск № 4. Киев : Ника-Центр, Эльга, 2003. 496 с.

4. Великий Ю.М., Чемчикаленко Р.А., Берегович В.Р. Оцінка стану фінансової стійкості вітчизняних підприємств. Глобальні та національні проблеми економіки. 2018. Випуск № 23. С. 465-469.

5. Гапак Н.М., Капштан С.А. Особливості визначення фінансової стійкості підприємства. Науковий вісник Ужсгородського університету. Серія : Економіка, 2014. Вип. 1 (42). С. 191-196.

6. Грушко В.І., Петриченко Л.Ю. Системна модель аналізу фінансової стійкості комерційних банків. Фінанси Украӥни. 2001. № 12. C. 20-26.

7. Кремень В.М., Шепетков С.Я. Оцінювання фінансової стійкості підприємства. Актуальні проблеми економіки. 2011. № 1 (115). C. 107-115.

8. Козлова О.С. Методика оцінки фінансової стійкості підприємства. Молодий вчений. 2017. № 10 (50). С. 914-918.

9. Павленко О.П., Семиліт І.В. Економічна сутність фінансової стійкості підприємств: фактори впливу, оцінка та джерела фінансування. Молодий вчений. 2016. № 7. С. 113-116.

10. Слободян Н.Г. Аналіз і прогнозування фінансової стійкості підприємства в сучасних умовах: методологія і практика. Економічний аналіз. 2014. № 18 (2). С. 239-245.

11. Шаблиста A.M. Фінансова стійкість підприємства: сутність та методи оцінки. URL: http://eip.org.ua/docs/EP_06_2_46_ uk.pdf (дата звернення: 01.09.2020).

\section{References:}

1. Abryutina M.S. (2006) Otsenka finansovoy ustoychivosti i platezhesposobnosti rossiyskikh kompaniy [Assessment of the financial stability and solvency of Russian companies] Finansovyy menedzhment, no. 6. pp. 28-34.

2. Belyalov T.E., Oliynyk A.V. (2016) Finansova stiykist' pidpryyemstva ta shlyakhy yiyi zmitsnennya [Financial stability of the enterprise and ways to strengthen it]. Mizhnarodnyy naukovyy zhurnal «Internauka», no. 12 (22), part. 2, pp. 22-26.

3. Blank I.A. (2003) Upravleniye finansovoy stabilizatsiyey predpriyatiya [Enterprise financial stabilization management]. Kyiv: Nika-Tsentr. El'ga. (in Russian)

4. Velykyy Yu.M., Chemchykalenko R.A., Berehovych V.R. (2018) Otsinka stanu finansovoyi stiykosti vitchyznyanykh pidpryyemstv [Assessment of the state of financial stability of domestic enterprises]. Hlobal'ni ta natsional'ni problemy ekonomiky, no. 23. pp.465-469. 
5. Hapak N.M., Kapshtan S.A. (2014) Osoblyvosti vyznachennya finansovoyi stiykosti pidpryyemstva [Features of determining the financial stability of the enterprise]. Naukovyy visnyk Uzhhorods'koho universytetu. Seriya Ekonomika, no. 1 (42), pp. $191-196$.

6. Hrushko V.I., Petrychenko L.YU. (2001) Systemna model' analizu finansovoyi stiykosti komertsiynykh bankiv [System model of analysis of financial stability of commercial banks]. Finance of Ukraine, no. 12, pp. 20-26.

7. Kremen' V. M., Shepetkov S. Ya. (2011) Otsinyuvannya finansovoyi stiykosti pidpryyemstva [Assessment of financial stability of the enterprise]. Aktual'ni problemy ekonomiky, no. 1 (115). pp. 107-115.

8. Kozlova O.S. (2017) Metodyka otsinky finansovoyi stiykosti pidpryyemstva [Methods for assessing the financial stability of the enterprise]. Molodyy vchenyy, no. 10 (50), pp. 914-918.

9. Pavlenko O.P., Semylit I.V. (2016) Ekonomichna sutnist' finansovoyi stiykosti pidpryyemstv: faktory vplyvu, otsinka ta dzherela finansuvannya [Economic essence of financial stability of enterprises: factors of influence, estimation and sources of financing] Molodyy vchenyy, no. 7, pp. 113-116.

10. Slobodyan N.H. (2014) Analiz i prohnozuvannya finansovoyi stiykosti pidpryyemstva v suchasnykh umovakh: metodolohiya i praktyka. [Analysis and forecasting of financial stability of the enterprise in modern conditions: methodology and practice] Ekonomichnyy analiz, no. 18 (2), pp.239-245.

11. Shablysta A.M. Finansova stiykist' pidpryyemstva: sutnist' ta metody otsinky [Financial stability of the enterprise: essence and methods of estimation]. Available at: http://eip.org.ua/docs/EP_06_2_46_uk.pdf (accessed 01 September 2020).

Dokiienko Larysa

International University of Finance

\section{CONCEPTUAL APPROACHES TO THE DIAGNOSIS OF FINANCIAL STABILITY OF THE ENTERPRISE}

The article is considered the classification of types of financial stability of the enterprise with their full characteristic. So, the main classification features of the financial stability of the enterprise are as follows: by the time of the assessment, by level of financial stability, financial stability as a certain financial condition, according to the level of provision of stocks with sources of their financing and by the characteristic of time. Also, the article describes the methods of diagnosis and methodological tools for assessing the main types of financial stability. Coefficient model for assessing the current financial stability of the enterprise is proposed to be used in terms of indicators, which characterize the effectiveness of management of capital structure, assets and cash flows of the enterprise. For a comprehensive assessment of financial stability based on this model is proposed all coefficients group in a matrix divided into two classes depending on the presence of the normative value. This will diagnose 5 states of financial stability of the enterprise: very high, high, normal, acceptable, satisfactory and unsatisfactory. It is proposed to diagnose financial stability as a certain financial condition of the enterprise based on the use of a model of modified balance with a division into generalized and differentiated scales. It allows you to identify areas of ideal or sufficient financial stability, financial equilibrium, and state of tension or risk areas. The main emphasis in the article is on substantiating the need for a comprehensive diagnosis of the financial stability of the enterprise, based on the use of a system model, which allows you to manage financial stability in the context of the factors that determine it in the current or future periods. A practical tool for determining the appropriate state of financial stability in the context of the system model is developed matrices of possible states and situations of the system model. They allow with full confidence assess the state of financial stability in a certain period as an approximation to the ideal or equilibrium or the maximum difference between the desired state and the state of danger.

Key words: financial stability, diagnosis of financial stability, types of financial stability, coefficient model of financial stability assessment, modified balance sheet model, system model of financial stability assessment.

JEL classification: E44, G32 